\title{
Determinants Influencing Accounting Quality of Transportation Service Firms
}

\author{
Thi Hong Le Hoang, Thi Bich Hanh Chu, Thi Bach Tuyet Vuong \\ University of Transport Technology, Vietnam \\ Manh Dung Tran \\ National Economics University, Vietnam
}

\begin{abstract}
The study aimed to determine what determinants influencing the accounting of transportation service firms working the area of Da Nang of Vietnam. A study model was developed, investigated and analyzed with the involvement of 250 transportation service firms in Da Nang. The results show five determinants influencing the accounting works including industry characteristics; legal guidance; material facilities for accounting; interest in accounting of business owners; accountants' qualifications. Among them, the two most important determinants influencing the quality of the accounting were legal guidance and interest in accounting of business owners. Based on the findings, some recommendations were made to improve the quality of accounting of transportation service firms.
\end{abstract}

Keywords: Determinants, accounting, transportation services

DOI: $10.7176 /$ RJFA/11-4-08

Publication date: February $29^{\text {th }} 2020$

\section{Introduction}

According to the Vietnamese Accounting Law No. 88/2015/QH13, accounting involves organizing the implementation of accounting standards and regulations to reflect the financial positions and operating performance, carrying out the accounting inspection and the accounting bookkeeping, supplying accounting documents and information and other accounting tasks. In addition, the Vietnamese Accounting Law also stipulates that accounting entities must organize the accounting apparatus with accountants arranged or hired. From such viewpoints and different approaches to and interpretations of accounting, it is recognized that accounting is one of the current concerns of businesses. Together with the function of information and inspection of businesses' financial position and performance on a regular, prompt and systematic manner, accounting does not simply mean the organization of management within a business, but also also includes the art of establishing elements, conditions as well as interactions that affect, directly or indirectly, the accounting work, to maximize its inherent functions, thus significantly contributing to supplying information in a timely, complete and honest manner for the operations management at both the macro and micro levels, enabling businesses to closely manage their assets against any corporate asset appropriation.

According to Ngo and Luu (2013), there are three forms of accounting, namely: concentrated, distributed, and both concentrated and distributed forms.

* Centralized form: all accounting tasks such as document classification, initial document inspection, accounting treatment, detailed accounting, costing, reporting and economic information are fulfilled in a centralized manner at the entity's accounting an no accounting is done by firms

* Distributed form: Accounting tasks are carried out simultaneously in the entity's accounting department and the affiliates' accounting divisions.

* Centralized and distributed form: This is a combination of the two foregoing forms. Accounting tasks are conducted in the entity's accounting department and the accounting divisions of the respective affiliates with accounting apparatus. For those dependent without accounting apparatus, their documents are collected to the entity's accounting department to record in accounting books.

The matching of accounting to the scale of operation, production and business characteristics and management requirements is critical to improving operational efficiency and quality of corporate accounting information, meeting both internal and external users' demand for corporate useful information. It is a common practice that accounting of transportation service businesses is weak and has no effect except as a tool to deal with the requirements of regulatory authorities. There are commonly two book-keeping systems in businesses, one of which is used for reporting to the tax authorities with the prescribed contents and format but reflecting no actual operating results of the business.

There have been various works of the accounting information system and its quality such as McLean \& Delon (2003). They measured the success of an information system by determinants such as system quality, information quality and service quality and applied a new research model developed. The study by Soderstrom \& Sun (2007) suggests that the determinants of accounting information quality in application of International financial reporting 
standards (IFRS) include legal and political systems, accounting standards and presentation of financial statements, among which, legal and political systems influence the quality of accounting in different ways with possible direct or indirect impact on the accounting information quality through accounting standards and report presentation. The study of Beest et al. (2009) conducted the research titled Quality of financial reporting: measuring qualitative characteristics which sheds light on the quality of financial reporting through the measurement of characteristics based on IASB viewpoint. Given the qualitative characteristics of accounting information required by IASB (2008) and previous studies on the assessment of qualitative characteristics, 21 determinants were developed for five qualitative characteristics as proposed by IASB (2008) of appropriateness, presentation and faithfulness, comprehensibility, comparability, promptness.

It can be seen from international studies found many determinants influencing the quality of firm accounting information, which are the same or different. Furthermore, the level of influence of the same determinant varies by country due to different research methods (based on secondary data or questionnaire), different business scales (large or medium and scale) or different economic and political conditions of countries.

In the context of Vietnam, scientists focused on accounting by reviewing related theoretical issues, conducting surveys and comparison to understand and evaluate accounting of firms using qualitative methods rather than employing quantitative approach. So in this research, we use quantitative methods with data collected through questionnaire surveys and processed and analyzed by SPSS to test determinants and to analyze the suitability of the model for investigating the impact levels of determinants on accounting of transportation service firms.

\section{Literature review and hypotheses}

The study was carried out on the basis of information theory, asymmetric theory and representational theory.

Information theory: Information theory, also known as communication theory, is applied in accounting through the design of information encoders. Encrypting computer-based accounting information in a scientific way enables managers to access data quickly and easily, avoiding confusion attributable to the same data and name-based management of information objects, for example, documents with the same names, amounts and contents in daily business transactions. This also helps distinguish and organize the accounting work in a separate, clear and scientific manner, best facilitating the synthesis, classification, inspection, reconciliation and reporting.

Asymmetric theory (also known as Asymmetric Information Theory) was first introduced in the 1970s. In 2001, the authors of this theory, Akerlof, Spence and Stiglitz were awarded the Nobel Prize in Economics. Information Asymmetry on the stock market occurs when business managers intentionally cover unfavourable information, exaggerates beneficial information and provide unreliable and poor-quality information on financial statements. Investors are often passive in gathering information, most of which is collected from the disclosures on the financial statements and verified by investors through auditors' reports. Therefore, the development of accounting improves the quality of financial reporting and minimizes information asymmetry.

The representational theory was derived from economic theory, developed by Alchian and Demsetz in 1972 and further improved by Jensen and Meckling in 1976. It refers to the contractual relationship between the company owner and the manager - the representative to act on behalf of the company. According to representational theory, both the manager (representative) and shareholders (owners) acts towards maximizing their own benefits; thus, in some cases, the manager will not work for the sake of the shareholders but seek to maximize his/her own benefits (self-interest). The question is how to cause the manager to work for the benefit of the owner while they have the advantage of information and the labor and capital market is not perfect. The representational theory proposed the following theoretical solution for such problem: to minimize the self-interest of the manager due to shareholders' failure to monitor all their activities and to limit losses to shareholders, shareholders must pay the representational costs.

Based on the results of McLean \& Delon's accounting quality determinant model and successful information system model in association with the analysis of the research and theoretical issues related to accounting of transportation service businesses, the model of study on determinants affecting the quality of accounting of transportation service businesses was hypothesized to include the following:

\section{H1a: Operating characteristics of transportation service firms have an impact on accounting.}

Transportation service is a special material production industry, whose products are the process of moving goods and passengers from one place to another and measured in tons, kilometres, number of goods and passengers without a material form. The production and consumption of transportation products are inseparable in the absence of storage procedures. Therefore, the impact of operations in transportation businesses on accounting is derived from the following: transportation service businesses manage their operations in different stages such as transactions, cargo and passenger transportation contracts, payments for contracts, logistics scheduling, etc.; Operational plans need to be specific for each day, week, etc.; the management must be elaborated for drivers who mainly work outside, with a proper material regime and assignment mechanism; The necessity for the norms of fuel and energy consumption for means of transport which are mostly fixed assets greatly affect the accounting of transportation service revenue and expenses. Transportation process depends on infrastructure, roads and natural 
conditions.

\section{H1b: The legal system affects the quality of accounting}

Transportation operators are mainly small and medium businesses operating under the control of the legal system. The "Legal accounting document system" in high-to-low-level order consists of accounting law, accounting standards, accounting regulations, circulars on guidance or supplement and amendments if any. There are currently two accounting systems in use, namely the mainland European accounting system and the Anglo-Saxon accounting system. In the countries using the mainland European accounting system such as France, Spain, Germany, etc., accounting regulations are usually issued by the state, highly consistent and based on the laws with less role of the professional associations. As for the countries using the Anglo-Saxon accounting system such as the United Kingdom, the United States, and so on, accounting regulations established by professional organizations, independent organizations or non-governmental organizations, are highly flexible and professional judgment with the dominant and key role of the accounting standards in the accounting practice. The Vietnamese accounting system is influenced by the mainland European accounting system in general and French accounting in particular. In Vietnam, the Ministry of Finance organizes and is responsible for issuing legal documents on accounting.

H1c: Accounting human resources influence the quality of accounting.

According to Chidiebere et al. (2014), accounting skills enhance business acumen and drive corporate growth. Functioning to record, synthesize and provide economic information to managers and users of accounting information, accounting plays a significant role in a company's internal control system (Thacker, 1994). Through the review of the foregoing studies on accounting roles, it is recognized that accounting resources are the decisive core of the accounting system. With the direct information generation, qualifications and accountability of the accounting system accompanies the quality of accounting information provided. If a company has a strong accounting department, which works in a professional manner, the information provided by the accountants will be accurate, the financial statements and reports will be clear, sufficient and good in terms of objectives and quality, thus helping executives a lot. In addition, good accountants know how to save the maximum cost for the company. Thanks to their prompt response to work, many costs of using the accounting apparatus in the business will be reduced.

H1d: Interest in accounting of business owners affects the quality of accounting.

Corporate governance and financial reporting quality have been dealt with in various studies all over the world. According to Bauwhede (2001), the potential determinants impacting financial statements includes: Managerial decisions (e.g., decisions on applied accounting policies, debt treatment, inventory management, asset liquidation, etc.), external management (e.g., auditing quality), internal management, financial reporting regulations, legal systems, and financial structures, distribution between ownership and control, needs and objectives of financial statements. Al-Hiyari et al. (2013) published a study of the determinants influencing the accounting information system and its quality. Information quality is believed to depend on human resources and management commitment which refers to an overall commitment involving not only the engagement of managers and authorized officers but also intra-group work and inter-group work to achieve smooth communication throughout the entire organization, information system, data quality. It is observed from the above studies that managerial thinking and management policies of the management have a great impact on financial reporting quality. Managerial accounting is primarily responsible for collecting and providing appropriate and prompt information for managers to operate and control the entity's operations and decision-making. Financial reporting quality will be abandoned if managers ignore the accounting information provided during their decision-making whilst focusing merely short-term benefits on the basis of their past experience. Consequently, accounting of businesses has no function other than falsely meet the requirements of regulatory authorities. In contrast, if managers build long-term development strategies for businesses and rely on accounting information to make plans and decisions, accountants' reports are required to be of high quality.

\section{H1e: Material facilities affect the quality of accounting.}

Accounting in the context of information technology (IT) application is the application of IT achievements in the collection, processing, outputting and archiving of accounting data in an automatic and accurate manner. According to Nguyen (2010) and with reference to the book titled "Corporate Accounting", HACQ Economics University, 2012, in accounting of a business, the material facilities there govern the determination of the accounting department structure, the assignment of accounting staff, the organization of accounting accounts coding, and the choice of the accounting forms applied to businesses.

\section{Research methodology \\ Scale development}

The study was conducted through interviews with accountants and directors of transportation service business between September 2017 and April 2018. The questionnaire was designed with reference from previous studies (McLean \& Delon, 2003). The pilot questionnaires with a set of determinants related to the research model were delivered to 10 participants, consisting of 4 directors or legal representatives, four chief accountants and two 
accountants of transportation service businesses with the purpose of assessing its comprehensibility and word expressions and then revised before the formal survey (Table 1). The scale used was a 5-score Likert scale with 1 score for totally disagreeing and 5 scores for totally agreeing.

\section{Table 1: Determinants and Its attributes}

\begin{tabular}{|c|c|}
\hline Codes & Details \\
\hline \multicolumn{2}{|c|}{ Transportation service characteristics } \\
\hline TSC1 & Transportation services are carried out in a short time, being convenient for recording. \\
\hline TSC2 & A short duration of transportation services facilitates timely circulation of accounting documents. \\
\hline TSC3 & Purchased materials are used directly for each service, favourably helping the materials management. \\
\hline TSC4 & Establishment of the material consumption norms makes it easy to account for revenue and expenses. \\
\hline \multicolumn{2}{|r|}{ Legal guidance } \\
\hline LEG1 & The legal accounting framework for businesses matches the operating situation of businesses. \\
\hline LEG2 & $\begin{array}{l}\text { The accounting regulations in accordance with current guidelines are clear and sufficient to meet the } \\
\text { needs of recording and processing data in the entity. }\end{array}$ \\
\hline LEG3 & The supplement to the legal accounting framework for business is the current necessity. \\
\hline LEG4 & Guidance on the accounting regulations is complete and easy to understand and follow. \\
\hline LEG5 & Guidance on the accounting books is complete, clear and easy to follow. \\
\hline LEG6 & Guidance on the accounting and accounts used is in line with businesses' operations. \\
\hline LEG7 & Guidance on the required financial reporting regulations matches businesses. \\
\hline LEG8 & Guidance of the tax authorities on making tax reports to state agencies is appropriate. \\
\hline \multicolumn{2}{|c|}{ Qualifications of accountants } \\
\hline ACQ1 & $\begin{array}{l}\text { Accountants are able to record, process and report accounting information that is relevant to the } \\
\text { entity's operations. }\end{array}$ \\
\hline ACQ2 & $\begin{array}{l}\text { Accountants who are able to read and understand the accounting regulations help completion of the } \\
\text { entity's accounting apparatus organization and preparation of valid reports. }\end{array}$ \\
\hline ACQ3 & Improving qualifications of accountants is necessary for the entity to develop sustainably. \\
\hline ACQ4 & The entity should not transfer or replace accounting staff to or with other departments'. \\
\hline ACQ5 & Accounting reports at the entity are highly appreciated by the auditing agencies \\
\hline \multicolumn{2}{|c|}{ Interest in accounting of business owners } \\
\hline IAB1 & The business owner reads and understands the information presented on the financial statements. \\
\hline IAB2 & The personnel of the entity's current accounting apparatus is redundant. \\
\hline IAB3 & The information on the accounting reports is the basis for managers to make managerial decisions. \\
\hline IAB4 & It is necessary for the business owner to attend accounting classes for managers. \\
\hline IAB5 & $\begin{array}{l}\text { The business owner should pay attention to the internal control and investment in the entity's internal } \\
\text { control system. }\end{array}$ \\
\hline IAB6 & Accounting information presented on the financial statements is satisfactory to the firm owner. \\
\hline \multicolumn{2}{|r|}{ Material facilities for accounting } \\
\hline MFA1 & $\begin{array}{l}\text { Material and technical facilities are really needed for the collection, processing and supply of } \\
\text { information. }\end{array}$ \\
\hline MFA2 & The business should use accounting software \\
\hline MFA3 & Accounting software used makes it easy for the accounting work at the entity. \\
\hline MFA4 & The LAN of the entity's accounting department works well in information sharing. \\
\hline MFA5 & The company should set up a Website and an Email for its operations. \\
\hline \multicolumn{2}{|r|}{ Quality of accounting of transportation service business } \\
\hline QOA1 & The entity’s accounting complies with current legal regulations. \\
\hline QOA2 & $\begin{array}{l}\text { Accounting information is provided in a prompt and complete manner, meeting the decision-making } \\
\text { needs of information users. }\end{array}$ \\
\hline QOA3 & The current accounting apparatus is suitable for the size of the entity. \\
\hline QOA4 & $\begin{array}{l}\text { The existing equipment and facilities of the entity meet the accountants' needs for data entry and } \\
\text { recording. }\end{array}$ \\
\hline
\end{tabular}

\section{Sample and data collection}

The surveyed subjects were transportation service businesses in Da Nang. Samples were taken using the convenience method, one of the non-probability methods of sampling in which researchers approach the sample elements in a convenient manner. That is, researchers can choose elements they can access (Nguyen and Nguyen, 2011).

According to Hoang and Chu (2008) for factor analysis techniques, the sample size is at least 4 or 5 times larger than the number of variables. Thus, the number of observational variables of the study was 32 , the minimum sample size was 128. From the viewpoint of Tabachnich \& Fidell (2007), in the multiple linear regression (MRL) analysis, the sample size is calculated by the formula $n \geq 50+8 p$, where $n$ is the sample size, $p$ is the number of 
independent variables in the model with 5 independent variables in the study, the sample size was at least 90 . Da Nang was chosen for the survey because it is home to diverse business and commercial activities. 250 questionnaires were delivered and 176 valid questionnaires were collected with the response rate of $70.4 \%$.

Table 2. Characteristics of surveyed subjects

\begin{tabular}{llr}
\hline & \multicolumn{1}{c}{ Criteria of assessment } & $\begin{array}{r}\text { No. of } \\
\text { participants (\%) }\end{array}$ \\
\hline \multirow{2}{*}{ Gender } & Male & $80(45.5 \%)$ \\
\cline { 2 - 3 } & Female & $96(54.5 \%)$ \\
\hline \multirow{2}{*}{ Position } & Director & $88(50 \%)$ \\
\cline { 2 - 3 } & Chief Accountant & $56(32 \%)$ \\
\cline { 2 - 3 } & Accountant & $32(18 \%)$ \\
\hline \multirow{3}{*}{ Legal form } & Joint Stock Firm & $18(10.2 \%)$ \\
\cline { 2 - 3 } & Limited Liability Firm & $150(85.2 \%)$ \\
\cline { 2 - 3 } & Private Firms & $2(1.13 \%)$ \\
\cline { 2 - 3 } & Others & $6(3.47 \%)$ \\
\hline
\end{tabular}

\section{Data analysis}

Multivariate analysis of the survey data was used with Cronbach's alpha of larger than 0.7 and Corrected ItemTotal Correlation of larger than 0.3 (Hair et al., 2006; Nunnally \& Burnstein, 1994). Next, Exploratory Factor Analysis (EFA) was conducted to evaluate the appropriateness, unidirection and convergence of determinants with $\mathrm{KMO} \geq 0.5$, total explanatory variance of $\geq 50 \%$ and factor loading of greater than 0.5 (Hair et al., 2006); to assess the relationships between the determinants in the correlation analysis model used' finally, to test the hypotheses of regression analysis using the ordinary least squares (OLS) with statistical significance of 5\%.

\section{Research results}

Scale results

The results of the scale tests show that the determinants were internally consistent, Cronbach's Alpha was greater than 0.7, and the observed variables after removing those with small Corrected Item-Total Correlation has Corrected Item-Total Correlation of greater than 0.3. EFA reveals that the set of observable variables in each factor was unidirectional scales and the factor analysis was consistent with the study data. KMOs were greater than 0.5 , TVE was greater than 50\%, factor loading (after removing unsatisfactory IAB1 and LEG5) was greater than 0.5.

Table 3: Assessment Results of Reliability of Factor Scale

\begin{tabular}{|c|c|c|c|c|c|}
\hline Determinants & $\begin{array}{l}\text { Cronbach's } \\
\text { Alpha (No. of } \\
\text { variables) }\end{array}$ & $\begin{array}{l}\text { Corrected } \\
\text { Item-Total } \\
\text { Correlation }\end{array}$ & KMO & $\begin{array}{l}\text { TVE } \\
(\%)\end{array}$ & $\begin{array}{c}\text { Min } \\
\text { Factor } \\
\text { Loading }\end{array}$ \\
\hline Transportation service characteristics & $.760(4)$ & $.489-.536$ & & & .721 \\
\hline Legal guidance & $.902(8)$ & $.500-.814$ & & & .679 \\
\hline Accountants' qualification & $.795(5)$ & $.488-.639$ & & & .651 \\
\hline Interest in accounting of business owners & $.891(6)$ & $.495-.811$ & & & .768 \\
\hline Material facilities for accounting & $.860(5)$ & $.564-.745$ & & & .671 \\
\hline Quality of accounting & $.733(4)$ & $.404-.611$ & .613 & 55.876 & .615 \\
\hline
\end{tabular}

\section{Correlation analysis}

The analysis results show that the mean scores on the effects of determinants on the quality of accounting and those in the model were between 2 and 3 in the Likert 5-score scale and the standard deviation (SD) of the determinants were also pretty small (Table 4). In particular, the legal factor was observed to have a great effect on quality of accounting of transportation service businesses (Mean $=3.902, \mathrm{SD}=0.807$ ) and the factor with the smallest effect on the quality of accounting was the characteristics of transportation services (Mean $=2.528, \mathrm{SD}$ $=0.619)$. The correlation analysis results reveal that the determinants within the model are interrelated $(\mathrm{r} \neq 0)$.

Table 4: Correlation matrix and scores for each factor

\begin{tabular}{ccccccccc}
\hline Variables & Mean & SD & QOA & LEG & IAB & MFA & ACQ & TSC \\
\hline QOA & 3.774 & .620 & 1 & & & & & \\
LEG & 3.902 & .807 & $.625^{* *}$ & 1 & & & & \\
IAB & 3.523 & .730 & $.485^{*}$ & $.315^{* *}$ & 1 & & & \\
MFA & 3.807 & .769 & $.610^{* *}$ & $.599^{* *}$ & $.233^{* *}$ & 1 & & \\
ACQ & 3.734 & .571 & $.583^{* *}$ & $.465^{* *}$ & $.313^{* *}$ & $.508^{* *}$ & 1 & \\
TSC & 2.528 & .619 & $-.274^{* *}$ & $-.116^{* *}$ & $-.143^{* *}$ & $-.223^{* *}$ & -146 & 1 \\
\hline
\end{tabular}

Hypothesis testing results

The results of the regression model show that the quality of accounting is positively influenced by four determinants: legal guidance (LEG), interest in accounting of business owners (IAB), facilities of accounting 
(MFA) and accountants' qualifications (ACQ) and negatively influenced by the transportation service characteristics (TSC). Consequently, the study model's hypotheses H1a, H1b, H1c, H1d and H1e were accepted. In terms of the standardized beta coefficient, the most influential factor in the quality of accounting is legal guidance (LEG) with a standardized beta regression coefficient of 0.280 , followed by interest in accounting of business owners (IAB) with a standardized Beta regression coefficient of 0.250 , facilities of accounting with a standardized Beta regression coefficient of 0.238, accountant's qualifications (ACQ) with a standardized Beta regression coefficient of 0.236 and finally transportation service characteristics (TSC) with a standardized Beta regression coefficient of 0.118 .

\section{Conclusions and Recommendations}

The determination of determinants influencing the quality of accounting of transportation service firms in the area of Da Nang will help stakeholders identify the number of determinants and their extent of influence accounting of these businesses. Consequently, stakeholders will make their own judgment and develop policies to build accounting and provide solutions to improve accounting of transportation service businesses for supply of quality, clear, accurate and complete information.

In consideration of the previous studies and related theoretical foundations, the study identified five primary determinants that affect the quality of accounting of transportation service businesses in Da Nang and were measured by 28 observable variables. These determinants were transportation service characteristics, legal guidance, material facilities for accounting, interest in accounting of business owners and accountants' qualifications.

Through EFA, two variables IAB1 and LEG5 were removed. After such removal, the factor scale reached the reliability. Factor loading of variables was greater than 0.5 and the factor loading difference of each observable variable was greater than 0.3 . A post-corrected scale was used for correlation analysis, multiple linear regression analysis and ANOVA analysis, etc.

The results of the multiple linear regression analysis show that the analysis model was suitable. Of five determinants, transportation service characteristics had a negative effect on the quality of accounting of transportation service businesses in Da Nang. Increasing the values of the remaining four variables would lead to an increased value of quality of accounting variable.

Thus, transportation service businesses in Da Nang can improve their quality of accounting based on the increase and decrease in the value of each of the following determinants: industry characteristics, legal guidance, material facilities for accounting, interest in accounting of business owners and accountants' qualifications.

The results show that the legal guidance had the strongest influence on the quality of accounting of transportation service businesses in Da Nang $(\beta=0.28)$. That means when the legal guidance is increased by 1 , the quality of accounting increases by 0.28 . Businesses in general and those operating in transportation services, in particular, are governed by the legal system on the national management mechanism in which they are operating. The operations of transportation service businesses must follow the State regulations. Therefore, appropriate legal guidance for transportation service businesses positively affects the quality of accounting.

The results also show the strong correlation between interest in accounting of business owners and the quality of accounting $(\beta=0.250)$. In other words, when interest in accounting of business owners increases by 1 , the quality of accounting increases by 0.25 .

Facilities were identified to be correlated with accounting organization quality $(\beta=0.238)$. Hence, when the material facilities increase by 1 , the quality of accounting increases by 0.238 .

The correlation between accountants' qualifications and quality of accounting was observed $(\beta=0.236)$. That means when accountants' qualifications increase by 1 , quality of accounting increases by 0.236 .

Transportation service characteristics were determined to have a negative effect on the quality of accounting $(\beta=0.118)$. Thus, accounting organization quality increases by 0.118 while transportation service characteristics decrease by 1 .

The overall objective of these conclusions was to improve the quality of accounting, enabling transportation service businesses to effectively organize their accounting apparatus and provide reliable financial statements for the users.

This study yielded certain results and contributions to users' understanding of determinants influencing the quality of accounting, thus orienting to develop more complete accounting and improve the accounting information quality. Nonetheless, some limitations of the study lied in its narrow sample size, limited in Da Nang city, leading an incomplete picture of all transportation service businesses with accounting across Vietnam.

\section{References}

Ngo. T. T. H., \& Luu, D. T (2013). Curriculum Accounting Organization in Business, Finance Publisher.

Hoang, T. \& Chu, N. M. N. (2008). Analysis of research data with SPSS (Vol. 1, 2). Hong Duc Publishing House. Nguyen, D. H. (2010). Accounting organization in the context of IT application. Accounting Journal, Spring Vol., 
24-27.

International Accounting Standards Board - IASB (2009). International Financial Accounting Standards for Small and Medium-Sized Businesses (IFRS for SMEs).

Nunnally, J. \& Burnstein, I.H. (1994). Pschychometric Theory. $3^{\text {rd }}$ Ed., New York: Mc Graw-Hill.

Thacker, R. J. (1994). Accounting Principles. Statistics Publishing House.

Al-Hiyari, A., Hamood, M. J., Al-Mashre, H., Mat, N. K. N. Mohammed, J. H. (2013). Factors that Affect Accounting InformationSystem. Implementation and Accounting Information Quality: A Survey in University UtaraMalaysia.

Jensen, M. C. and Meckling, W. H. (1976). Theory of firm: managerial behaviour, agency costs and ownership structure. Journal of Financial Economics, 38(4), 305-360.

Hair, R. Anderson, R. Tatham, W. Black. (1998). Multivariate Data Analysis, 5th Ed. Prentice Hall International, London.

Beest, F. V., Braam, G., \& Boelens, S. (2009). Quality of Financial Reporting: measuring qualitative characteristics. Nice Working paper 09-108, April 2009.

Soderstrom, N. S., Sun K. J. (2007). IFRS Adoption and Accounting Quality: A Review, European Accounting Review, 16(4), 675-702. 